IdeAs

Idées d'Amériques

$17 \mid 2021$

Villes et culture dans les Amériques

\title{
The American Library Association and the American Library in Paris: A 100 Year Legacy and Connection in the Archives
}

Cara S. Bertram

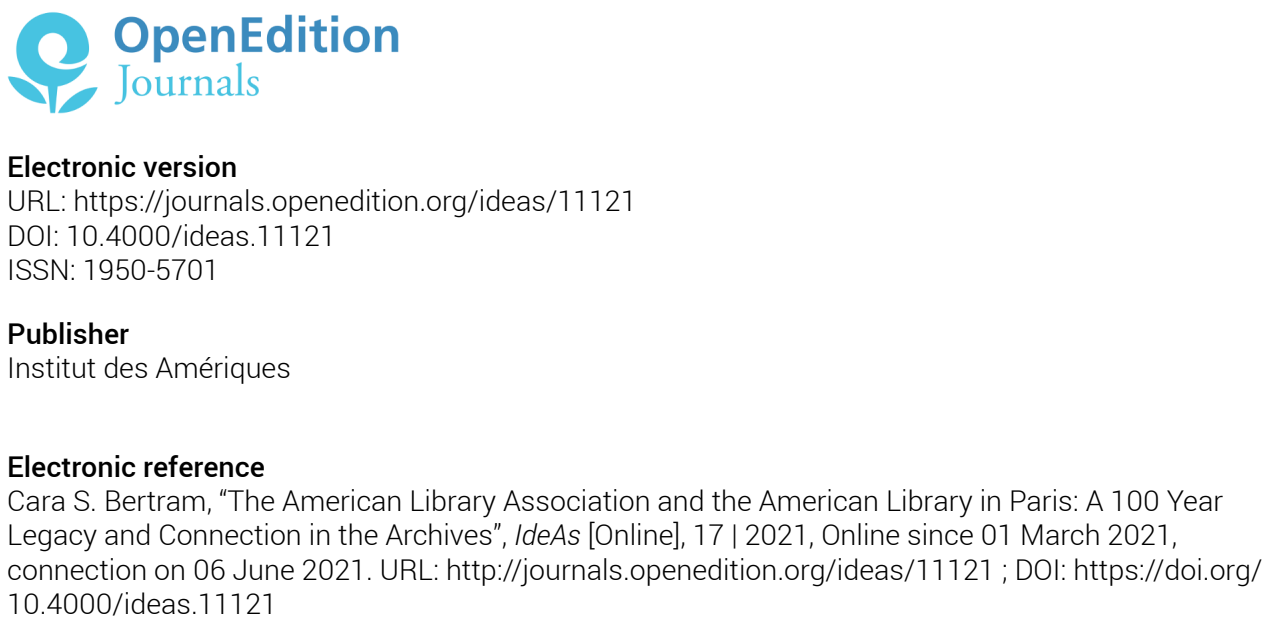

This text was automatically generated on 6 June 2021.

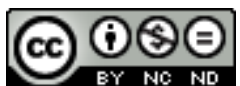

IdeAs - Idées d'Amériques est mis à disposition selon les termes de la licence Creative Commons Attribution - Pas d'Utilisation Commerciale - Pas de Modification 4.0 International. 


\title{
The American Library Association and the American Library in Paris: A 100 Year Legacy and Connection in the Archives
}

\author{
Cara S. Bertram
}

1 The American Library Association (ALA) was founded on October 6, 1876, on the last day of a three-day meeting for the Conference of Librarians during the Centennial Exposition in Philadelphia. Now known as the largest and oldest library association in the world, the ALA started with humble beginnings. Prior to 1917, the association was an insular professional organization rather than driven by advocacy and service. Burton Stevenson, a librarian and writer, described it during this period as "merely a humdrum professional organization, wrapped around with tradition, settled in its habits of thought, and chiefly occupied with matters of technical detail" (Wiegand W., 1986: 235).

2 However, the United States' entry into World War I spurred the association into action. During the 1917 ALA Annual Conference in Louisville, Kentucky, the ALA established the Library War Service (LWS), a far-reaching public engagement program to provide books and library services to American soldiers in military camps in the United States and abroad. The ALA Library War Service became the most ambitious public service program launched by the association at the time and its efforts were a surprising success for a little-known professional organization with just over 3,300 members.

While many of ALA's initiatives after World War I did not see the same success, the LWS produced lasting legacies, including a strong spirit in leadership and public service. The American Library in Paris (ALP) stands as one of the ALA's most enduring legacies of its World War I service. Understanding and researching ALA's volunteer efforts in WWI and the establishment and support of the ALP is essential to comprehending the beginnings of ALA's drive towards public service and its increasing work in international librarianship. 


\section{The Library War Service and the American Library in Paris}

4 The LWS focused on fundraising and collecting books from the public, establishing and staffing military camp libraries primarily in the United States, and providing library services in military hospitals. By 1920 , the LWS raised $\$ 5$ million in public donations, established thirty-six camp libraries, provided library collections to over 500 locations, and over one thousand volunteers participated in the service.

Despite a heavy domestic focus during the war, a limited number of ALA representatives were allowed into France. These representatives coordinated with other volunteer services, such as the YMCA and Red Cross, to distribute books to American service members on the front. ALA's overseas service, headed by McKendree Raney and then Burton Stevenson, initially lacked a permanent headquarters. In the summer of 1918, ALA was invited by the YMCA to share a facility at 10, rue de l'Élysée, allowing ALA to establish a more stable presence in Paris. The move resulted in ALA's Paris Library opening on August 29, 1918. The library served as ALA's headquarters in France, a library for soldiers and English-speaking residents in France, and as an example of an American public library (Young A., 1981: 66-67).

The LWS continued its work after the armistice and more American librarians were allowed into Europe. Service continued to be the forefront of the LWS's mission as the librarians were focused on keeping up the morale of American soldiers who were waiting to return home from military camps and hospitals in Europe. The programs ranged from just providing a space to read to education and job training to prepare American soldiers returning to civilian life. In July 1919, librarian and ALA's publicity officer, Mary Eileen Ahern, reported a soldier telling her that the books were the only things that kept him sane (Ahern M. E., 1919: 312).

7 By the end of 1919, many of the LWS's activities were wrapping up. The ALA transferred much of its wartime collection and functions to the US federal government. However, there were questions as to what would happen to the ALP and its collection. There was general interest from the English-speaking public to maintain the library. In a report made during an ALA conference, Executive Secretary Carl Milam noted, "The Paris library is going on whether we do anything about it or not. American business men [sic], English speaking people, have become interested - thrilled - with the idea of continuing the Paris library" ("Special A. L. A. Conference," 1920: 4).

With support for continuing the library, in 1920, the ALP was established. Despite becoming an independent entity, the ALP and the ALA remained intertwined. The association provided funding for ALP's operations in its first couple of years and it appointed one third of ALP's board of trustees (Thomison D., 1978: 93). While no longer as interconnected as before, ALA still maintains a representative on ALP's board of trustees, a relationship that has lasted the past 100 years. This connection between the two organizations, from its origins with the LWS to present day, is represented within the American Library Association Archives. 


\section{The Library War Service in the Archives}

9 The story of the LWS lives as nearly forty cubic feet of archival records within the ALA Archives at the University of Illinois at Urbana-Champaign. This body of archival materials contains extensive correspondence, reports, publications, booklists, newspaper clippings, photographs and glass slides, scrapbooks, and posters. Arthur P. Young, in his research for his history on the LWS, noted that the archives preserved approximately 30,000 pages of correspondence and 10,000 newspaper and magazine clippings on ALA's WWI activities (Young A., 1981: 115).

10 The strength of this collection is its diversity; administrative records mixed with publicity, publications, photographs, and personal papers create a complex and rich history of ALA's wartime service. The success that ALA enjoyed was not without its obstacles. While newspaper clippings and articles touted ALA's triumphs, letters between leadership reveal the insecurities of the association as few people knew what the acronym ALA stood for. Reports and correspondence show occasional conflicts with the YMCA and Red Cross that arose over control of certain operations or who received credit for supplying and distributing reading materials. Laments written home and to ALA Headquarters show how books and magazines disappearing in transport hindered efforts to stock library shelves and to get books into the hands of soldiers.

11 The papers of ALA's volunteers add another perspective, providing personal insights into the LWS. Librarian Harriet Long's letters home detail her work with soldiers stationed along the US-Mexican border and her struggles with a lack of help, boxes of books gone wayside, and situations that made her want to "use strong language, quite unbecoming to a lady and librarian" (Harriet C. Long Papers). Charles Greene's papers reveal his rapid appointment as a much-needed reference librarian at Camp Johnston in Florida, then his immediate promotion as Acting Librarian, all before ever setting foot on the campgrounds. His papers demonstrate the ever-changing circumstances and flexibility of ALA's volunteers (Charles R. Green Papers). A letter found in Mary Eileen Ahern's papers reveals a great kindness she did in locating the grave in France of a fallen American soldier for his family and shows the impact she had beyond librarianship (Mary E. Ahern Papers). These personal accounts and recollections add life to the administrative records of the LWS.

The ALA Archives also holds a rich collection on the LWS's publicity. Colorful posters were produced to raise awareness for books drives and fundraising campaigns. Glass lantern slides with photographs of servicemen using camp and hospital libraries were used by ALA representatives in the United States to demonstrate the need for books and magazines. The slides were also used in military camps to advertise the services provided by the camp library. Postcards depicting shipments of books, camp libraries, and wounded soldiers enjoying books urged the American public to donate funds, magazines, and books.

13 An increasing amount of the ALA Archives records on the LWS are being digitized by archives staff and with help from the Digitization Services Unit of the University of Illinois Library. All the glass lantern slides and postcards used in ALA's publicity efforts are scanned and readily available online. WWI posters are also digitized and available upon demand. Scrapbooks from the war service have undergone conservation work and are in the process of being digitized to be made publicly available. 
Beyond the visual materials, a portion of the papers of ALA's volunteers are also available online, most notably the Caroline Webster Papers. Webster's papers provide an invaluable look into the beginnings of library hospital services. Future projects hope to focus on digitizing more textual materials, including the War Service Correspondence, 1917-1923, which is composed of forty-seven bound volumes of letters and reports produced by the LWS.

\section{Finding the American Library in Paris in the Archives}

15 While the LWS records are easily found within a single sub-group of records within the ALA Archives, the materials on the ALP are not so neatly organized. Archives are not arranged by subject and are instead organized by creator or provenance. This means that the records produced by ALA's LWS fall under one grouping. However, since the ALP is not an ALA office or division, it can require diligent research to find information on ALP within the ALA Archives.

Searching for the ALP within the ALA Archives shows which ALA offices and units interacted with or were discussing the ALP. Folders and materials relating to the ALP are found in the records of several ALA units, such as the LWS, ALA International Relations Office, the Executive Director's Office, ALA Presidents, in membership papers, and ALA publications, dating back to the origins of the ALP. These scattered archival materials within the ALA Archives reflect the interwoven and lasting relationship between the ALA and the ALP.

17 Finding information on the ALP within the LWS records can be surprisingly challenging. When approaching the search for records covering the origins of the library, researchers must remember that the library was not initially called the ALP. Reports, speeches, and letters refer to the library by several names, such as the Paris Library, ALA Headquarters in Paris, ALA Headquarters in France, or just Headquarters Library. Sources for ALP's LWS origins can be found in the extensive collection of War Service Correspondence, organized under ALA's overseas activities in France (War Service Correspondence). Searching the Bulletin of the American Library Association, the official publication of the ALA until 1938, also yields information on the ALP during its early years in articles and reports. The ALA Annual Conference Proceedings are another rich, if unexpected, resource for the ALP's early history. The conference proceedings that cover the Great War provide detailed reports of ALA's activities from representatives and leadership, the impact of their work, and transcripts of discussions and speeches. The discussion and incorporation of the ALP as a separate entity can be found in the 1920 ALA Annual Conference Proceedings.

Many of the records at the ALA Archives cover the ALA in the interwar years and WWII. The bulk of records from the ALA International Relations Office on ALP covers 1920 to 1945. A record series on correspondence between the International Relations office and ALP is composed of letters to and from Jessie Carson, Edward Sumner, Milton Lord, and H.M. Lydenberg, amongst others. Another series of materials contains pamphlets, postcards, and publications promoting ALP's services and outlining its history. There are also files from the American Legion Conference in 1927, including letters, memoranda and brochures relating to ALA's assistance to the ALP's service to the American Legion Paris Conference. 
Another resource for ALP interwar and WWII history is within the records of ALA Executive Director's office, ALP Correspondence ("American Library in Paris Correspondence, 1922-1945"). This series of three boxes offers significant correspondence from ALP directors Dorothy Reeder and Clara de Chambrun, who both provide insights of working at the library under German occupation. The Althea H. Warren Papers, the ALA President from 1943 to 1944, also contains further information on ALA's WWII activities and its relationship with ALP.

Another avenue of research is the ALP's short-lived Paris Library School founded in 1923. Under the direction of librarian and assistant secretary of ALA, Sarah Bogle, and sponsored by the American Committee for Devastated France, the school was set up to train librarians in American methodologies in France. However, financial troubles plagued the school, and it ceased operations in 1929 (Thomison D., 1978: 94). Four boxes of correspondence, reports, student lists, and budgets make up the Paris Library School File.

The papers of Foster E. Mohrhardt provide a picture of the continued relationship between ALA and ALP beyond the World Wars. Mohrhardt served on the ALP board of trustees from 1965 to 1973 . His papers contain meeting minutes, project files, and a proposal to move the ALP from 1973.

Perhaps the resource that most shows off the long-standing relationship between the two organizations is the ALA Executive Board and Council meeting minutes and documents. Continued discussion and updates are brought before ALA's governing body, reflecting the importance of the connection. As recently as the 2020 ALA Midwinter Meeting, ALA Council voted and approved of a resolution congratulating the ALP on its centennial and the transcript of the discussion is preserved in the ALA Archives ("Council III Transcript").

Portions of the Executive Director's American Library in Paris Correspondence is digitized and available online. As is the entire series on the American Legion Conference. Portions of the ALP Pamphlet and Publication file are also digitized for researchers to use. Other less obvious sources are also digitally available, such as the ALA Conference Proceedings, and the Executive Board and Council proceedings. While only a small percentage of the records on the ALP are digitized, researcher interest has grown with the centennial of the library. Due to the increased interest, the ALA Archives is looking towards opportunities for scanning more of the Executive Director's and International Relations Office's correspondence files on the ALP.

\section{BIBLIOGRAPHY}

Ahern, Mary Eileen, “A. L. A. News from Overseas,” Bulletin of the American Library Association, vol. 13, n 3, July 1919.

“Special A. L. A. Conference," Bulletin of the American Library Association, vol. 14, n 1, January 1920. 
Thomison, Dennis, A History of the American Library Association, 1876-1972, Chicago, American Library Association, 1978.

Wiegand, Wayne A., The Politics of an Emerging Profession: The American Library Association, 1876-1917, New York, Greenwood Press, 1986.

Young, Arthur, Books for Sammies: The American Library Association and World War I, Pittsburgh, Beta Phi $\mathrm{Mu}, 1981$.

\section{AUTHOR}

\section{CARA S. BERTRAM}

Cara S. Bertram is an archives program officer at the University of Illinois at Urbana-Champaign. She manages the operations of the American Library Association Archives and provides reference services for the University of Illinois Archives. She earned both her BA in history and MA in history with a certificate in archives and records management at Western Washington University. cbertra@illinois.edu 